TESTING OF MATERIALS 
Other titles of interest from Macmillan

Hull \& John: Non-destructive Testing

John: Introduction to Engineering Materials, 2nd edition

Hall: Polymer Materials, 2nd edition

John: Engineering Materials (College Work Out)

Ryder: Strength of Materials 


\section{TESTING OF MATERIALS}

VERNON JOHN

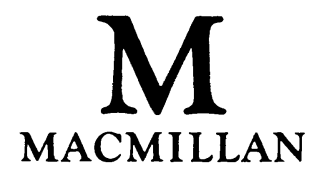


(C) V. B. John 1992

All rights reserved. No reproduction, copy or transmission of this publication may be made without written permission.

No paragraph of this publication may be reproduced, copied or transmitted save with written permission or in accordance with the provisions of the Copyright, Designs and Patents Act 1988 or under the terms of any licence permitting limited copying issued by the Copyright Licensing Agency, 33-4 Alfred Place, London WC1E 7DP.

Any person who does any unauthorised act in relation to this publication may be liable to criminal prosecution and civil claims for damages.

First published 1992 by

MACMILLAN EDUCATION LTD

Houndmills, Basingstoke, Hampshire RG21 2XS

and London

Companies and representatives

throughout the world

Typeset by

TecSet Ltd, Wallington, Surrey

ISBN 978-0-333-44783-3 ISBN 978-1-349-21969-8 (eBook)

DOI $10.1007 / 978-1-349-21969-8$

A catalogue record for this book is available from the British Library 


\section{Contents}

Note on Standards

vii

Acknowledgements

vii

Chapter 1 The Requirements for Testing

1.1 Introduction; 1.2 The Need for Testing; 1.3 Material Property Tests; 1.4 Non-destructive Testing.

Chapter 2 Hardness and Its Measurement

2.1 The Property of Hardness; 2.2 Mohs' Scale of Hardness;

2.3 Static Indentation Tests; 2.4 The Brinell Hardness Test;

2.5 The Vickers Diamond Hardness Test; 2.6 The Rockwell

Hardness Test; 2.7 Microhardness Testing; 2.8 The Knoop

Diamond Microhardness Test; 2.9 The Shore Scleroscope Test;

2.10 Relationships between Hardness and Other Properties;

2.11 Self Assessment Questions.

Chapter 3 Tensile, Compressive and Shear Tests

3.1 Stress and Strain; 3.2 Testing Machines; 3.3 Measurement of Strain; 3.4 The Tensile Testing of Metals; 3.5 The Tensile Testing of Plastics; 3.6 Determining the Tensile Strength of Brittle Materials; 3.7 Compression Testing; 3.8 Testing in Shear; 3.9 Significance of Test Results; 3.10 Self Assessment Questions.

Chapter 4 Sheet Metal Tests

4.1 Introduction; 4.2 Controlled Bend Tests; 4.3 Reverse Bend Tests; 4.4 The Erichsen Test; 4.5 The Jovignot Cupping Test; 4.6 Cup Drawing Tests; 4.7 Self Assessment Questions

Chapter 5 Notch Impact and Fracture Toughness Testing

5.1 Fracture; 5.2 Temperature Effects and the Ductile-brittle transition; 5.3 Notch Impact Tests; 5.4 The Izod Notch Impact 
Test; 5.5 The Charpy Notch Impact Test; 5.6 Notch Impact Values; 5.7 Fracture Toughness Determination; 5.8 Crack Opening Displacement Testing; 5.9 Self Assessment Questions.

Chapter 6 Fatigue and Fatigue Testing

6.1 Fatigue; 6.2 Factors Affecting Fatigue; 6.3 Fatigue Testing;

6.4 Significance of Test Results; 6.5 Self Assessment Questions.

Chapter 7 Creep and Creep Testing

7.1 Creep; 7.2 Presentation of Creep Data; 7.3 Creep Resistant Alloys; 7.4 Creep Testing; 7.5 Stress-rupture Testing;

7.6 Relaxation Testing; 7.7 Significance of Creep Test Results;

7.8 Self Assessment Questions

\section{Chapter 8 Non-destructive Testing}

8.1 Introduction; 8.2 Visual Inspection; 8.3 Liquid Penetrant Inspection; 8.4 Principles of Penetrant Inspection; 8.5 Advantages, Limitations and Applications of Penetrant Inspection; 8.6 Magnetic Particle Inspection; 8.7 Magnetisation Methods; 8.8 Advantages, Limitations and Applications of Magnetic Particle Inspection;

8.9 Electrical Test Methods; 8.10 Inspection Frequency and Coil Types; 8.11 Phase Analysis; 8.12 Advantages, Limitations and Applications of Electrical Methods; 8.13 Ultrasonic Testing; 8.14 Ultrasonic Probes; 8.15 Ultrasonic Display; 8.16 Techniques for Defect Detection; 8.17 Applications of Ultrasonic Testing; 8.18 Principles of Radiography; $8.19 \mathrm{X}$-rays and $\gamma$-rays;

8.20 Obtaining and Assessing a Radiograph; 8.21 The Radiation Hazard; 8.22 Advantages, Limitations and Applications of Radiography; 8.23 Self Assessment Questions

Answers to Self Assessment Questions

Appendix : Some Relevant British and American Standards 133 Index 


\section{Note on standards}

The majority of testing methods for material properties are standardised. Each major country possesses its own standards institutions. The standards for a particular test procedure, for example the testing of metals in tension, will be similar from one country to another but may differ on some points of detail such as the specific dimensions of test pieces. In general, references in the text are made to British Standards but in some cases, where there is no appropriate British Standard, an ASTM (American) standard is quoted. A list of relevant British and American standards is given in the Appendix. Extracts from British Standards are reproduced by permission of BSI. (Complete copies of the standards can be obtained from them at Linford Wood, Milton Keynes, MK14 6LE.)

\section{Acknowledgements}

I would like to thank Harry Beasley for the time and effort he put in to produce the photographic illustrations for this book. I would like also to thank my wife, Gillian, for her full support throughout the preparation of this text and for converting my barely legible scrawl into type.

Vernon John 